\title{
FORMS AND METHODS OF EDUCATIONAL WORK WITH PRIMARY SCHOOL CHILDREN WHILE TEACHING THE BASICS OF FIRE SAFETY
}

\section{ФОРМИ ТА МЕТОДИ ВИХОВНОЇ РОБОТИ 3 МОЛОДШИМИ ШКОЛЯРАМИ ПРИ НАВЧАННІ ОСНОВ ПОЖЕЖНОЇ БЕЗПЕКИ}

\section{Oleksandr Cherkashyn ${ }^{1}$}

DOI: https://doi.org/10.30525/978-9934-588-53-2-24

Abstract. According to the statistics, 272411 fires broke out over the last five years in Ukraine, in which 16756 persons died, including 484 children; 8396 persons were injured, 722 of them children; 19157 persons were rescued, including 1499 children. The statistical data and performed analysis of causes of fire occurrence and their tragic consequences are indicative of low preparedness of children between ages 5 and 10 for actions in case of fires that is reflected in the ignorance of elementary fire safety regulations. The theoretical and methodological basis of the research is the provisions of the current legislative and regulatory acts in the field of educational work of primary school children; the content of fire safety in the educational process of primary school children. Unfortunately, notwithstanding a considerable variety of theoretical materials on fire safety, which primary school children work with, and their good practical implementation in educational out-ofschool activities, the results related to availability of certain fire safety knowledge in children need to be improved. Firstly, it is associated with small amount of hours devoted to Fire Safety elaboration and unavailability to carry out a comprehensive practical training of theoretical knowledge obtained during school lessons and still not worked out teaching method and practice of correct actions during fire. Secondly, only inconsiderable part of material deals with fire safety issues. Thirdly, in our opinion, there are insufficiently successful works of informative materials related to

\footnotetext{
${ }^{1}$ Candidate of Pedagogical Sciences,

Senior Lecturer at Department of Fire and Rescue Training,

National University of Civil Defence of Ukraine, Ukraine

(C) Oleksandr Cherkashyn
} 
practice of main safety fire requirements. So, I think that involvement of fire safety experts would encourage freshening up knowledge of fire prevention materials and its successful practice with primary school children. The collaborative efforts to develop the main text related to fire safety and guidelines for its practical use would be helpful to the first step for planting fire safety culture in younger pupils thanks to self-protection knowledge, abilities and skills in case of fire hazard. As can be seen from the above, we can assert that fire safety preparation of primary school children does not produce expected results today. So, there is urgent need to refine theoretical materials related to fire safety issues in educational process of younger pupils and application of more efficient forms and methods of educational work with children in the field of fire safety in order to implement them in practice for higher level of pupils' preparedness for self-protection in the presence of fire hazard that is a conceptual basis for further research.

\section{1. Вступ}

Незнання дітьми елементарних правил пожежної безпеки, на превеликий жаль призводить до виникнення пожеж, травмування та загибелі у них дітей. Згідно зі статистичними даними [3], тільки за останні п’ять років в Україні виникло 272411 пожеж, у яких загинуло 16756 людей, у тому числі 484 дитини; отримали травми 8396 людей, 3 них 722 дитини; було врятовано 19157 людей та 1499 дітей. Так, діти не знають, що таке безпечний та небезпечний вогонь; що собою представляють загорання та пожежа, яку користь та небезпеку вони несуть для життя; основні причини виникнення загорань та пожеж, їх можливі наслідки; основні правила запобігання пожежі; порядок доповіді про пожежу до Служби порятунку та основні ії складники; поняття про Службу порятунку; порядок дій у разі виникнення загорання або пожежі; не знають та не вміють правильно вийти із задимленого приміщення; не знають та не вміють загасити одяг, який загорівся; не знають, що таке евакуація, а також місця їх розташування в умовах пожежонебезпечних ситуаціях.

Як результат:

- із задимленого приміщення вони просто вибігають на вулицю замість того, щоб виходити поповзом, уникаючи при цьому отруєння димом; 
- загоряння одягу гасять руками та бігають туди-сюди, замість того, щоб впасти на підлогу і таким чином загасити загорання;

- при виникненні пожежі у квартирі ховаються під ліжко або зачиняються у іншій кімнаті, тим самим вказують на рятування життя таким способом, що вкрай небезпечно;

- дехто, вийшовши 3 квартири, буде користуватися ліфтом при пожежі;

- були випадки, коли діти пропонували рятуватися через вікно 3 верхніх поверхів багатоповерхового будинку;

- займаний електроприлад, який знаходиться під напругою, гасять водою;

- олію в сковороді теж гасять водою, що в таких випадках приводить до розбрискування горючої суміші, наслідком чого є отримання опіків.

Ці факти свідчать про необхідність вибору та обгрунтування ефективних форм та методів виховної роботи зі школярами для вдосконалення знань про пожежну безпеку. Актуальність проблеми спричинює також пошук та обгрунтування ефективних форм і методів виховної роботи з молодшими школярами.

Аналіз досліджень та публікацій показав, що проблемі формування у школярів знань про пожежну безпеку присвячена невелика кількість розвідок, найвагомішими серед яких є праці О. Ващенко [1], I. Гуріненко [2], А. Попкова [4], В. Сидоркина [5], Л. Скрипник [6], М. Удовенко [7], А. Якупова [8] та ін., однак досі формування знань учнів молодшого шкільного віку про пожежну безпеку в позанавчальній діяльності не було предметом комплексного фахового дослідження.

Метою статті $є$ аналіз та теоретичне обгрунтування найбільш ефективних форм і методів виховної роботи з молодшими школярами для формування знань у сфері пожежної безпеки. Провідними завданнями є опис наявних форм і методів виховної роботи зі школярами в навчальний та позанавчальний час, аналіз їх ефективності, виокремлення головних складників основ пожежної безпеки, опис впровадження їх основних положень у виховний процес початкової школи.

\section{2. Добір форм і методів формування протипожежних знань}

Важливим складником формування навичок з основ пожежної безпеки є ефективний добір форм та методів виховної роботи. На мою 
думку, найбільш дієвими будуть ті форми й методи, які зможуть найбільше вплинути на свідомість і поведінку дітей молодшого шкільного віку, оскільки виявляться цікавими й доступними для їх вікової категоpiï, сприятимуть творчому пошуку та розвитку мислення, даватимуть можливість не лише отримувати знання, а й застосувати їх на практиці для реалізації завдань, пов'язаних із самозахистом у разі виникнення небезпеки життю. Під час навчання дітей молодшого шкільного віку основ пожежної безпеки доцільним, на нашу думку, буде акцентування уваги школярів на профілактиці виникнення пожеж та порядкові дій у разі їх виникнення. Важливо не лише опановувати теоретичні знання, а й відпрацьовувати практично відповідні вміння за допомогою різноманітних форм та засобів навчання й виховання.

Найпоширенішим методом виховної роботи 3 дітьми у сфері пожежної безпеки є бесіда, яка є найбільш доступною для дітей молодшого шкільного віку. Бесіда відіграє передусім інформаційну та комунікативну роль при освоєнні дітьми основ пожежної безпеки. Застосування цього методу дає можливість ознайомлювати дітей з головними правилами пожежної безпеки, причинами виникнення пожеж, із тим, що таке безпечно чи небезпечно, основними правилами запобігання пожежам, порядком дій у разі виникнення загорання чи пожежі. Доповненням бесіди може виступати роздача інструкцій та пам'яток 3 інформацією та кольоровими зображеннями, що є відповідними віковим особливостям молодших школярів. Важливою є подальша інформаційна підтримка - створення особистої та шкільної протипожежної бібліотеки, яка забезпечить молодшим школярам доступ до інформації з основ пожежної безпеки не лише на слуховому, а й на візуальному рівнях.

Більш ефективним метод бесіди буде у випадку співпраці вчителя та учнів із спеціалістами Державної служби України з надзвичайних ситуацій під час екскурсії школярів до пожежної частини, виступів представників пожежної охорони на класних годинах, у пришкільних таборах та в період літньої оздоровчої кампанії. Це дасть змогу сформувати почуття відповідальності за збереження майна та речей, усвідомити можливість загрози виникнення пожежі, виробити необхідну обережність у поводженні з вогнем, електроприладами, газовими приладами, свічками, сірниками тощо. 
Тематичні екскурсії до пожежної частини на етапі початкової школи, на мою думку, є важливим складником організації навчання дітей окремих напрямів пожежної безпеки. Під час тематичних екскурсій відбувається спілкування, бесіда зі спеціалістами рятувальної справи, ознайомлення зі схемами евакуації у разі виникнення пожежі. Важливою, на мій погляд, є пізнавальна подорож та ознайомлення 3 професіями та діями рятувальника й диспетчера - від моменту прийому диспетчерами телефонного дзвінка про пожежу, або якусь надзвичайну подію, до моменту локалізації та ліквідації (повного гасіння) пожежі чи ліквідації надзвичайної події, ознайомлення з аварійно-рятувальною технікою. Завдяки цій формі роботи в дітей формується уявлення про професію рятувальника, іiі роль у нашому житті. Діти починають краще розуміти важливість дотримання правил пожежної безпеки, усвідомлювати небезпеку пожежі та їі наслідків, адже лише під час екскурсії діти отримують можливість поговорити про пожежі 3 професійними рятувальниками, дізнатися про негативні моменти виникнення небезпечних ситуацій, проаналізувати необхідність набуття знань $з$ профілактики виникнення пожеж, правильного алгоритму дій, виходячи з прикладів реальних життєвих ситуацій, про які розкажуть фахівці в процесі екскурсії.

Під час тематичних екскурсій до пожежних частин важливу роль відіграє знайомство дітей з роботою диспетчера. Побачивши наочно статистику дзвінків за добу до Служби порятунку, діти матимуть можливість краще усвідомити шкоду від фальшивих (хибних) дзвінків; зрозуміти, наскільки важлива достовірна та повна інформація про пожежу, або подію; дізнатися, що саме слід казати, викликаючи пожежних; зрозуміти важливість швидкого прийому інформації та передачі іiі рятувальникам заради безпеки свого життя та життя оточуючих людей. Учні усвідомлять, що незнання усіх необхідних даних про місце виникнення пожежі, координат місцевості, де виникла пожежа, призведе до затримок у роботі пожежних, і це, своєю чергою, може спричинити трагічні наслідки. Водночас діти матимуть змогу перевірити власні, уже наявні, знання з безпеки своєї життєдіяльності.

Виробленню у школярів знань 3 пожежної безпеки сприятимуть також лекції, практичні заняття, участь у тематичних вечорах, вікторинах, виготовлення плакатів з пожежної тематики, випуск стінгазети 
пожежного спрямування, участь у конкурсі протипожежних малюнків, відвідування музеїв пожежної охорони, показ плакатів, відео-, кінофільмів з протипожежної тематики, ігрові змагання та вікторини серед дітей. Ці форми та методи активно використовуються вчителями під час занять та в позакласній роботі, проте, ми вважаємо, що вони $\epsilon$ ефективними лише в комплексі з виробленням практичних навичок, адже поверхове теоретичне знайомство з пожежною безпекою не сприяє оволодінню глибокими знаннями, відтак і виробленню в учнів правильного алгоритму дій в разі виникнення пожежонебезпечної, або іншої небезпечної ситуації, що супроводжується пожежею.

Ще одним методом навчання основ пожежної безпеки, що активно впроваджується вчителями під час проведення занять, під час тижня безпеки життєдіяльності, класних годин, святкування дня захисту дітей, під час літньої оздоровчої кампанії, є тренувальна евакуація школярів та вчителів зі школи, певних приміщень чи будинків. Цей метод навчання є ефективним у засвоєнні учнями знань про порядок дій у разі виникнення пожежі та задимленості приміщень, набутті конкретних знань та навичок, але тільки за певних обставин. На сьогодні алгоритм прописаний так, що евакуація організується та проводиться безпосередньо під керівництвом педагогів. Ці практичні тренінги плануються завчасно, чітко контролюються, однак недоліком таких тренувальних евакуацій $є$ те, що учні не мають можливості самостійно обирати шляхи евакуації, відтак у них не відбувається вироблення та вдосконалення самостійно прийняти правильні рішення. Чинний алгоритм проведення тренувальних евакуацій передбачає, що педагоги виводять учнів з приміщень на вулицю в безпечне місце, перераховують евакуйованих та доповідають про наявність школярів директору школи чи заступникові. Цим нівелюється ефективність процесу відпрацювання навичок прийняття самостійних рішень і виконання самостійних дій. Школярі діють під керівництвом учителів в умовах недостатньої інформації про небезпеку, іiї впливу на людину, методи iї подолання та самозахисту. Тож, на мою думку, тренувальний метод роботи має застосовуватися в тому числі й за умов надання учням повної самостійності під час виконання дій та прийняття рішень, щоб кожна дитина сама змогла прийняти рішення про евакуацію, визначити напрямки порятунку та його шляхи (через тамбури, коридори, еваку- 
аційні виходи, вестибюлі тощо). Педагог чи запрошений на ці заняття працівник Служби порятунку при цьому обмежиться функцією контролю. Серед його завдань буде завдати умови - змоделювати місце виникнення уявної пожежі та проаналізувати правильність дій школяра. Але етапові практичного відпрацювання умінь та навичок має передувати етап попереднього опрацювання теоретичного матеріалу.

Перед тренувальною евакуацією спочатку вчителям, а потім дитині слід розповісти про шляхи евакуації та евакуаційні виходи; показати, де вони розташовані у школі та куди ведуть. Цю інформацію має надавати спеціально запрошений представник місцевої пожежної охорони. Найефективнішим цей метод буде при взаємодії трьох сторін: рятувальники - педагоги - батьки. Завданням батьків у цьому випадку буде надання дітям необхідної протипожежної інформації відносно власної оселі, зокрема діти мають знати специфіку розміщення кімнат у квартирі (приватному будинку), шляхів евакуації з них, можливі варіанти виникнення пожежі та ймовірні шляхи порятунку у безпечне місце. Допомогти батькам з експертизою протипожежного стану оселі можуть рятувальники, спеціально запрошені для цього на батьківські збори.

Важливою умовою ефективності цього методу тренувань є систематичне, а не епізодичне (скажімо, раз на рік) проведення фахівцями протипожежної справи тренінгів із учителями, батьками та дітьми. Під час таких тренінгів мають створюватися проблемні ситуації, організовуватися ігри, обговорюватися типові виховні проблеми, відбуватися спільний критичний аналіз дій, моделюватися виховні ситуації, у процесі програвання яких дорослі будуть набувати необхідний обсяг знань, умінь і навичок. Важливо, щоб після кожного тренінгу з програванням тієї чи тієї ситуації у батьків і вчителів була можливість обговорити зі школярами, колегами, представниками Державних пожежно-рятувальних частин пережиті дітьми емоції; проаналізувати дії дітей, вислухати їхній аналіз щодо прийнятих у тій чи тій ситуації рішень, виявити недоліки, надати поради в доопрацюванні того чи іншого аспекту. У цих вправах необхідно виокремити смисловий аналіз дій дітей та виявити помилки для їх обговорення, виправлення в подальшому моделюванні життєвих ситуацій, що дозволить розвивати ініціативність дитини, уміння здійснювати дослідницький пошук, аналізувати та знаходити відповіді на складні питання, а також сприятиме покращенню психо- 
логічного стану вихованців, корекції їхньої поведінки та налагодженню взаємодії з небезпечним навколишнім середовищем.

Головним аспектом у формуванні в дітей молодшого шкільного віку необхідного обсягу знань, умінь та навичок з основ пожежної безпеки $€$ практично-ігрова спрямованість цих тренінгів. Найпростіші вправи можна організувати на подвір'ї школи, біля будинку, влітку - на території дитячих оздоровчих таборів. Як уже зазначалося, спочатку слід опрацювати $з$ учнями теоретичний матеріал, а вже потім переходити до практичного відпрацювання необхідних умінь та навичок. Прикладами моделювання пожежонебезпечних ситуацій можуть бути такі: учитель, батьки чи представник державної пожежної частини запалюють завчасно підготовлений папір у відрі, багаття на невеликому смітнику; може моделюватися ситуація, коли загорівся електроприлад, увімкнений в електромережу; загорівся рушник, який лежав поряд 3 увімкненою газовою піччю тощо. Це найпростіші завдання, при виконанні яких діти можуть наочно побачити можливі варіанти подолання пожежонебезпечної ситуації. Однак варто пам'ятати, що діти молодшого шкільного віку не повинні самостійно долати пожежонебезпечні ситуації, вони мають знати, що це може бути вкрай небезпечним, адже одна й та сама ситуація може розвиватися по-різному, й не всі ризики та небезпеки можуть бути ними враховані. Скажімо, типовий випадок загорання паперу в смітнику. Найпростішим варіантом подолання ситуації $є$ гасіння його водою, але не всі діти зможуть прорахувати ситуацію, що в смітнику можуть знаходитися додаткові горючі та легкозаймисті матеріали, які під дією високої температури виділяють їдкий дим; такі речовини можуть вибухнути, і це призведе до травмування. Перше, що мають чітко усвідомлювати діти молодшого шкільного віку - під час виникнення пожежі слід кликати на допомогу дорослих, а не займатися гасінням пожежі самостійно. Діти цього віку мають усвідомлювати також можливі наслідки своїх пожежонебезпечних дій. Зокрема: якщо б папір не було підпалено сірниками, він би не загорівся і не спричинив пожежонебезпечну ситуацію. Тим самим, гра $\epsilon$ доволі ефективним методом набуття молодшими школярами необхідних знань, умінь і навичок з основ пожежної безпеки, вона дає змогу ілюструвати приклади виникнення загорань та пожеж із життєвих ситуацій та моделювати поведінку дитини в небезпечних для життя 
умовах, сприяє формуванню самостійності вихованця на основі вже наявних у нього певних знань, умінь і навичок. При використанні ігрових методів для оволодіння навичками пожежної безпеки доцільним $\epsilon$ залучення до процесу навчання й виховання співробітників пожежної охорони. Це дозволить підвищити рівень знань дітей щодо дій у разі виникнення пожежі та відпрацювати правильний алгоритм дій.

Доречною ігровою вправою стало б і відпрацювання доповіді молодшого школяра диспетчеру Служби порятунку про пожежу чи загорання. Такі вправи слід проводити за участю працівників ДСНС України, бо під наглядом професіоналів результати стануть ефективними в експерименті цього напрямку роботи. Заздалегідь обговорюється час та день, коли діти будуть телефонувати за номером «101» та вчитися правильно доповідати про вигадану нами пожежу. Спочатку такі відпрацювання слід проводити на основі невеликого уявленого загорання чи задимлення, яке вони побачили та повідомили про це дорослим та в Службу порятунку. У подальшому їх слід ускладнювати та з’єднувати дії дітей, щоб вийшов повний порядок дій.

Слід також зазначити, що в рамках відпрацювання тренінгів, ігрових вправ учні потребують консультативної допомоги різного характеру, наприклад, інформаційної (надання необхідної інформації для вирішення ситуативних проблем дитиною, розширення іiі знань та умінь), психологічної (подолання психологічних проблем, формування адекватної поведінки, поліпшення відносин із навколишнім середовищем), педагогічної (підвищення мотивації до навчання, допомоги для здійснення дитиною свідомого практичного вибору, орієнтації на використання своїх здібностей та реалізацію певних дій для самозахисту).

Інформація, отримана під час консультування, допоможе учням орієнтуватися в різних небезпечних життєвих ситуаціях, правильно реалізовувати свої дії, сформувати свою позицію відносно практичного вибору правильних дій самозахисту в умовах пожежної небезпеки.

Інша ігрова вправа, якій ми віддаємо належне місце у збереженні життя дитини - це правильна поведінка у разі задимлення приміщення. Тож тут віднайде своє місце гра, наприклад, з подолання задимленого приміщення та гасіння займаного одягу.

Під час таких ігрових вправ діти відпрацьовують алгоритми правильних дій. Завдяки постійному повторенню матеріалу та його прак- 
тичному відпрацюванню діти отримають можливість оволодіти навичками, які зможуть застосувати в реальному житті.

\section{3. Науковий експеримент. Аналіз ефективності}

Для підтвердження наукового пошуку щодо імовірного впливу на формування у молодших школярів знань про пожежну безпеку є правильний добір форм і методів роботи, спочатку було перевірено наявний рівень знань у школярів про пожежну безпеку, що виявився низьким. Потім впроваджено ігрові вправи у Липецьку загальноосвітню школу I-III ступенів Харківської районної ради Харківської області. У заході взяли участь 50 учнів молодших класів та 4 учителя.

За результатами проведеного експерименту ми виявили, що рівень знань молодших школярів підвищився, що говорить про ефективність форм і методів роботи в частині вивчення дітьми пожежної безпеки.

Так, у грі «Зателефонуй до Служби порятунку та розкажи про свою ситуацію» діти у перший раз, звичайно, дуже хвилювалися, неправильно доповідали, але диспетчера Служби порятунку допомагали їм, запитували у дітей, переправляли й підказували, що треба робити. Таким чином, розмова з першого разу тривала приблизно 15 хвилин, у другий раз -8 хвилин, третій раз -5 хвилин, і вже 3 четвертого та 3 п’ятого разів усі діти чітко та правильно за установленими правилами змогли доповісти про свої ситуації.

Після успішно відпрацьованої всіма дітьми певної ситуації, ми міняли ситуації між ними, про що заздалегідь попереджали диспетчерів Служби порятунку. Таким чином, кожна дитина змогла у десятьох запропонованих нами 3 життєвих ситуацій пожежонебезпечних прикладів правильно, та головне - за встановленим алгоритмом, доповісти про свої ситуації та надати всі необхідні дані.

Кінцевим результатом стало те, що діти впевнено розмовляли 3 диспетчерами та в найкоротший термін відпрацьовували доповідь про ситуацію. Як показує практика, жоден дорослий, який телефонує до Служби порятунку не може чітко за правилами доповісти про пожежу, як це робили молодші школярі, задіяні в нашому педагогічному експерименті.

У грі «Хто швидше» діти не хотіли повзти під хмарою диму, їм хотілося бігти, щоб перемогти, як це буває на уроках фізкультури. Тож ми умовили хлопчика з першої пари повзти, решта не схотіли це робити. 
Взявши папір з димом, ми стали посередині десятиметрової зони естафети. Водночас ми розгорнули напередодні приготовлений імітований дим. Після цього хлопчик з першої пари виходив із задимленого приміщення поповзом, а дівчинка з його пари бігла. Як наслідок, - хлопчик пройшов естафету під хмарою диму та вийшов на свіже повітря, а дівчинка, яка бігла, зупинилася посеред естафети, бо імітований нами дим завадив їй рухатися далі. Після цього наступні пари учасників змагань теж почали пересуватися поповзом, бо наочно побачили, що із задимленого приміщення можна вибратися тільки таким чином.

Ефективним виявилися також тренінги та ігрові вправи «Як загасити папір та ганчірку, що загорілися», «Як загасити електроприлад, що загорівся та загорання олії у сковороді», «Відчинення дверей i малювання плану евакуації», «Пожежа або загорання вдома», а також «Загаси на собі одяг».

\section{4. Рекомендації змісту пожежної безпеки для школярів}

Запропонована система ігрових вправ та завдань спрямована, передусім, на вироблення практичних вмінь та навичок в рамках навчального плану, охоплює увесь програмовий матеріал з пожежної безпеки для учнів 1-4 класів. У цих вправах основну увагу слід звернути, перш за все, на найтиповіші пожежонебезпечні ситуації з життя дітей, що вже були в країні з трагічними наслідками та, які можуть трапитися, а також визначити доступні шляхи подолання небезпеки. Здебільшого це стосується, коли дитина сама залишилась вдома. Такі тренувальні вправи спонукають молодших школярів до трансформування теоретичних знань в уміння та навички, що, своєю чергою, гарантує психологічну підготовку в умовах надзвичайних ситуацій. Адже небезпека та ризик травмування та загибель на пожежах зменшується, якщо така загроза стає предметом вивчення та практичного відпрацювання в умовах життєвої ситуації.

Для досягнення очікуваних результатів слід теж врахувати та дотримуватися певних критеріїв: правила гри повинні буди заздалегідь продумані, без складних сценаріїв та ролей, короткочасні. Дітей не слід виснажувати психологічно і фізично. Коротка за часом гра надасть дітям активної зацікавленості. Тому дітям обов'язково слід відпочивати. 
Розкриваючи теми пожежної безпеки для дітей, батькам варто не лише зосередитися на його позитивних якостях, а й змоделювати найтиповіші ситуації, як-от: що сталося б, якби людина не зателефонувала до Служби порятунку у разі виникнення пожежі чи зателефонувала iз великим запізненням; або, що було якби людина не знала як вийти правильно із задимленого приміщення та ін.

Під час вивчення основ пожежної безпеки 3 молодшими школярами варто врахувати той момент, що у разі виникнення перших ознак пожежі, побачивши невелике загорання, слід втекти від небезпеки (врятувати своє життя), та повідомити дорослих (батьків, вчителів, сусідів), або зателефонувати до Служби порятунку, адже під час пожежі кожна секунда має значення, відтак - по-перше, діти рятують собі життя, по-друге, чим швидше вони повідомлять дорослим або в Службу порятунку, тим швидше до справи візьмуться професіонали, що призведе до найменших збитків та втрат. У нагоді стануть уявні змодельовані ситуації, наприклад, загорання та пожежі, у першому випадку, у квартирі на першому поверсі чи будинкові, у другій ситуації, - на верхніх поверхах багатоповерхового будинку.

У таких випадках не можна гасити дитиною самій будь-яке загорання. Слід наголосити на тому, що дитина, ймовірно, може переоцінити свої можливості та розпочне власними силами гасити пожежу, не знаючи основних понять процесу розвитку та припинення горіння, чим зумовить ризик своєму життю та здоров'ю.

Це особливо актуальним є сьогодні, коли учні не бачать на власні очі пожежу чи загорання, як-от: електроприладу чи побутового приладу, олії в сковороді тощо; та не знають з власного досвіду, яку руйнівну силу має пожежа та якими є їі наслідки.

Тим самим, доцільно звертати увагу школярів на важливість першочергових дій з саморятування від небезпеки, позаяк у дитини ще не має достатнього власного досвіду для адекватного сприйняття пожежонебезпечної ситуації, тому існує загроза насамперед недооцінювання ймовірних ризиків у небезпечних ситуаціях. Прикладом $є$ виникнення пожежі в квартирі, загорання сіна чи бензину в сараї, де багато горючих та легкозаймистих матеріалів, що у разі виникнення пожежі призведуть до швидкого іiі розповсюдження та за лічені секунди стануть поштовхом для швидкого іiі розвитку. 
Тож, беручи до уваги реальні обставини з життя рятувальників, що базуються на особистому досвіді, включаючи їх матеріал під час розробки форм та методів роботи та впровадження їх у виховний процес, можна вирішити проблему незнання молодшими школярами основ пожежної безпеки. Це, своєю чергою, посприяло б першим крокам до формування у дітей знань про пожежну безпеку.

У молодших школярів на основі знань необхідно сформувати швидкі та ефективні дії у певному просторі з обмеженим часом. Суттєво досягти правильних дій в умовах смертельної загрози та дефіциту часу на порятунок можна лише завдяки систематичним тренінгам. Важливим результатом цих практичних відпрацювань повинно стати те, що кожна дитина має діяти не в межах свідомого сприйняття і самостійної організації діяльності, а на основі вивченого алгоритму.

До обгрунтованих форм та методів виховної роботи, які на мою думку є найбільш ефективними для формування знань у молодших школярів про пожежну безпеку, пропоную включити такий теоретичний зміст:

- що таке безпечний та небезпечний вогонь;

- що собою представляють загорання та пожежа, яку користь та небезпеку вони несуть для життя;

- основні причини виникнення загорань та пожеж, їх можливі наслідки;

- основні правила запобігання пожежі;

- порядок доповіді про пожежу до Служби порятунку та основні іiі складники;

- поняття про Службу порятунку;

- порядок дій у разі виникнення загорання або пожежі;

- як вийти із задимленого приміщення;

- як загасити одяг, який загорівся;

- що таке евакуація та основні ії шляхи;

а також передбачити практичні завдання, що охоплюють:

- порядок доповіді про пожежу до Служби порятунку;

- порядок дій у разі виникнення загорання або пожежі;

- алгоритм дій у разі задимлення приміщення;

- порядок дій, якщо загорівся одяг;

- евакуація з приміщення. 
Отже, запропонована характеристика та зміст форм і методів формування у молодших школярів знань про пожежну безпеку у виховній позакласній роботі грунтується на використанні інтерактивних методів роботи, що передбачає сплановану послідовність дій, спрямованих на правильне прийняття рішення самозахисту та безпечної поведінки в умовах пожежної небезпеки.

Зауважу, що це є здебільшого методи індивідуальної та групової форми роботи. Їх новизна полягає в тому, що вони адаптовані до здійснення правильних дій молодших школярів в умовах виникнення загорянь чи пожеж, або задимленості приміщення та спрямовані саме на їх підготовку до самозахисту. Дієвість цих форм та методів може забезпечуватися у всіх випадках пожежонебезпечних ситуацій, пов'язаних із будь-яким видом за складністю загорань чи пожеж, що передбачає однотипний найпростіший порядок дій, в чому і полягає їх цінність.

Корисним $є$ також використання в навчанні кращих здобутків української методики формування протипожежних знань у школярів, що активно використовувалася протягом 1910-1989 років. Робота 3 формування у дітей знань та навичок з питань пожежної безпеки була масштабною i всеохоплюючою, основним був практичний складник, який передбачав серед усього іншого проведення крупних змагань між дітьми з моделюванням різних вигаданих ситуацій, які можуть трапитися у житті та уведення в навчальні дисципліни предмета з рятувальної справи, однак різкий такий початок може призвести до психологічного навантаження та руйнівного впливу на моральну поведінку дітей. Адже кожна дитина може по-своєму сприйняти зруйновані будівлі, вогонь, крик людей, запах горілого, труп людини та ін. Такий підхід дійсно може бути застосованим у вирішенні окресленої нами проблематики та мати певні результати 3 формування у молодших школярів протипожежних знань та вирішенні питань проблем загибелі дітей у пожежах, однак цьому слід присвятити окреме психолого-педагогічне дослідження. Цей напрямок $є$ не менш перспективним для досліджень та, можливо, колись віднайде своє практичне застосування [9; 10].

Не менш ефективною формою навчання молодших школярів основам пожежної безпеки є дистанційна, зокрема через мережу спеціалізованих сайтів для дітей відповідних рятувальних та пожежно-ря- 
тувальних служб. Ця форма активно використовується у світовій пожежно-профілактичній діяльності.

На цих сайтах розміщується увесь комплекс навчально-методичного матеріалу, що у доступній формі розкриває основні питання пожежної безпеки, як от: дані про своє місце проживання; пожежа вдома; безпека під час новорічних свят; безпечні шляхи евакуації; безпека на воді; правила безпеки взимку та ін., що включає правила запобігання пожежі, причини виникнення пожежі та поетапний алгоритм дій у разі виникнення пожежонебезпечної ситуації. Теоретичний матеріал розміщується або тематичними блоками безпосередньо на сайті, або в інтерактивних електронних книгах, посилання на які є активними на цьому ж сайті.

Безпосереднім здобутків цих сайтів $є$ великий за обсягом практичний блок, що складається з самостійних вправ, інтерактивних ігор, розмальовок та ін., спрямованих на закріплення пройденого матеріалу учнями різних вікових категорій та рівня знань. Успішність виконання того чи того завдання, зазвичай, контролюється системою, відтак дитина може працювати з цими сайтами самостійно без допомоги батьків чи вчителів.

Безперечно, така форма роботи $є$ актуальною. Позитивним $є$ те, що цей комплекс навчальних матеріалів $є$ доступним для будь-якої дитини, незалежно від місця ії навчання чи проживання. Сдиною вимогою є те, що діти повинні мати доступ до комп'ютера чи іншого джерела, що має вихід до мережі Інтернет.

В Україні дистанційна форма навчання молодших школярів основам пожежної безпеки активно не використовується, про що можна лише пошкодувати, адже світовий досвід засвідчує, що навчання дітей основам пожежної безпеки через мережу спеціалізованих тематичних сайтів є доволі ефективним.

Таким чином, завершуючи обгрунтування форм та методів формування у молодших школярів знань про пожежну безпеку у виховній позакласній роботі, а також їх зміст, можна зробити такі висновки.

\section{5. Висновки й перспективи подальших розвідок}

У статті проведено теоретичне обгрунтування форм і методів виховної роботи з молодшими школярами при формуванні протипо- 
жежних знань. Використання методів бесіди, екскурсій до місцевих пожежних частин, навчальних евакуацій, ігор та тренінгів $є$ найбільш ефективними при формуванні знань, умінь і навичок з основ пожежної безпеки, але потребують комплексних методичних рекомендацій для вчителів і батьків, а також долучення до цього процесу фахівців з пожежної безпеки. До обгрунтованих форм та методів виховної роботи запропоновано їх теоретичний та практичний зміст 3 пожежної безпеки.

Запропонована характеристика та зміст форм і методів формування у молодших школярів знань про пожежну безпеку у виховній позакласній роботі грунтується на використанні інтерактивних методів роботи, що передбачає сплановану послідовність дій, спрямованих на правильне прийняття рішення самозахисту та безпечної поведінки в умовах пожежної небезпеки.

Зауважу, що це є здебільшого методи індивідуальної та групової форми роботи. Їх новизна полягає в тому, що вони адаптовані до здійснення правильних дій молодших школярів в умовах виникнення загорянь чи пожеж, або задимленості приміщення та спрямовані саме на їх підготовку до самозахисту. Дієвість цих форм та методів може забезпечуватися у всіх випадках пожежонебезпечних ситуацій, пов'язаних із будь-яким видом за складністю загорань чи пожеж, що передбачає однотипний найпростіший порядок дій, в чому і полягає їх цінність.

Для підтвердження наукового пошуку щодо імовірного впливу на формування у молодших школярів знань про пожежну безпеку є правильний добір форм і методів роботи, спочатку було перевірено наявний рівень знань у школярів про пожежну безпеку, що виявився низьким. Потім впроваджено ігрові вправи у Липецьку загальноосвітню школу I-III ступенів Харківської районної ради Харківської області. У заході взяли участь 50 учнів молодших класів та 4 учителя.

За результатами проведеного експерименту ми виявили, що рівень знань молодших школярів підвищився, що говорить про ефективність форм і методів роботи в частині вивчення дітьми пожежної безпеки.

Разом із цим, сьогодні існують й інші форми та методи виховної роботи, що допомагають формувати у молодших школярів протипожежних знань, і це потребує подальшого, більш грунтовного, дослідження. 


\section{Список літератури:}

1. Ващенко О. М. Формування у молодших школярів компетенцій безпеки життєдіяльності. Теоретико-методичні проблеми виховання дітей та учнівської молоді. 2014. Вип. 18. С. 99-106.

2. Гуріненко I. А. Дидактичні умови навчання правилам пожежної безпеки молодших школярів. Збірник наукових праць Уманського державного педагогічного університету імені П. Тичини. 2010. № 1. С. 60-69.

3. Державна служба України 3 надзвичайних ситуацій. Національна доповідь про стан пожежної та техногенної безпеки в Україні. Київ, 2020. URL: http://dsns.gov.ua (дата звернення: 03.05.2020).

4. Попков А. В. Формирование безопасного поведения подростков во внеурочной деятельности : дис. ... канд. пед. наук : 13.00.01. Ижевск, 2007. 270 с.

5. Сидоркин В. А. Психолого-педагогические условия формирования готовности школьников к организованным действиям при чрезвычайных ситуациях : дис. ... канд. пед. наук : 13.00.01. Москва, 2008. 242 с.

6. Скрипник Л. Ю. Формирование у подростков навыков пожарной безопасности в системе дополнительного образования : дис. ... кандидата педагогических наук : 13.00 .02 теория и методика обучения и воспитания. Москва, 2010. 234 с.

7. Удовенко М. А. Методика формування здоров'язбережувальної компетентності учнів початкової школи у процесі вивчення «Основ здоров'я». Засоби навчальної та науково-дослідної роботи. 2014. № 43. С. 238-246.

8. Якупов А. М. Школа, семья и среда в подготовке школьников основам пожарной безопасности. Технологии гражданской безопасности. 2004. № 3. C. 113-117.

9. Черкашин О. В. Навчання молодших школярів пожежній безпеці: сучасний стан проблеми. Наукові записки Тернопільського національного університету імені Володимира Гнатюка. 2016. № 3. С. 182-189.

10. Черкашин О. В. Основи пожежної безпеки в системі навчання та виховання молодших школярів. Вісник Житомирського державного університету імені Івана Франка. 2016. Вип. 3. С. 152-157.

\section{References:}

1. Vashchenko, O. M. (2014). Formuvannia u molodshykh shkoliariv kompetentsii bezpeky zhyttiediialnosti [Formation of the competences of life safety in the junior pupils]. Theoretical and methodological problems of raising children and students, vol. 18, pp. 99-106.

2. Hurinenko, I. A. (2010). Dydaktychni umovy navchannia pravylam pozhezhnoi bezpeky molodshykh shkoliariv [Didactic conditions for the training of fire safety rules for junior schoolchildren]. Collection of scientific works of Uman State Pedagogical University named after P. Tychyna, no. 1, pp. 60-69.

3. The State Emergency Service of Ukraine. Natsionalnaiia dopovid pro stan pozhezhnoii ta tekhnohennoii bezpeky v Ukraiini [National report on the state of fire and man-made safety in Ukraine]. Avaliable at: http://dsns.gov.ua/ (accessed 3 May 2020). 
4. Popkov, A. V. (2007). Formirovaniie bezopasnogo povedeniia podrostkov vo vneurochnoii deiatelnosti [Formation of safe behavior of adolescents in extracurricular activities], $(\mathrm{PhD})$, Izhevsk.

5. Sidorkin, V. A. (2008). Psikhologo-pedagogicheskiie usloviia formirovaniia gotovnosti shkolnikov k organizovannym deistviiam pri chrezvychainykh situatsiiakh [Psychological and pedagogical conditions for the formation of preparedness of students for organized actions in emergency situations], $(\mathrm{PhD})$, Moscow.

6. Skripnik, L. Yu. (2010). Formirovaniie u podrostkov navykov pozharnoii bezopasnosti $\mathrm{v}$ sisteme dopolnitelnogo obrazovaniia [Formation of fire safety skills in adolescents in adolescent education], $(\mathrm{PhD})$, Moscow.

7. Udovenko, M. A. (2014). Metodyka formuvannia zdoroviiazberezhuvalnoi kompetentosti uchniv pochatkovoi shkoly u protsesi vyvchennia «Osnov zdoroviia» [Methodology of formulating healthy's competency-based competencies in coaching school at the «Fundamentals of Health» process»]. Means of educational and research work, no. 43, pp. 238-246.

8. Yakupov, A. M. (2004). Shkola, semiia i sreda v podgotovke shkolnikov osnovam pozharnoii bezopasnosti [School, Family and Environment in Students' Training to the Fire Safety Basics]. Civil Security Technologies, no. 3, pp. 113-117.

9. Cherkashyn, O. V. (2013). Navchannja molodshykh shkoljariv pozhezhnij bezpeci: suchasnyj stan problemy [Teaching junior high school students fire safety: the current state of the problem]. Scientific notes of Ternopil National University named after Volodymyr Hnatyuk, no. 3, pp. 182-189.

10. Cherkashyn, O. V. (2016). Osnovy pozhezhnoji bezpeky v systemi navchannja ta vykhovannja molodshykh shkoljariv [Fundamentals of fire safety in the system of education and upbringing of junior schoolchildren]. Bulletin of Zhytomyr State University named after Ivan Franko, vol. 3, pp. 152-157. 